\title{
PHOTOCATALYTIC DEGRADATION OF RHODAMINE B IN HETEROGE- NEOUS AND HOMOGENEOUS SYSTEMS
}

\author{
ASFANDYAR KHAN ${ }^{1,2}$, ZSOLT VALICSEK ${ }^{1}$, AND OTtÓ HORVÁTH*1 \\ ${ }^{1}$ Department of General and Inorganic Chemistry, Center for Natural Sciences, Faculty of Engineering, \\ University of Pannonia, Veszprém, HUNGARY \\ ${ }^{2}$ Department of Textile Engineering, National Textile University Faisalabad, PAKISTAN
}

\begin{abstract}
This study focuses on the photocatalytic degradation of Rhodamine $B(\mathrm{RhB})$ in heterogeneous and homogeneous photoFenton reactions. In the heterogeneous system, iron(II) doped copper ferrite $\mathrm{Cu}_{(x)}^{\mathrm{II}} \mathrm{Fe}_{(1-x)}^{\mathrm{II}} \mathrm{Fe}_{2}^{\mathrm{III}} \mathrm{O}_{4}$ nanoparticles (NPs) prepared in our previous work were employed as potential catalysts. The photodegradation of RhB was carried out in a quartz cuvette located in a diode array spectrometer. The experimental conditions such as $\mathrm{pH}$, NPs dosage and $\mathrm{H}_{2} \mathrm{O}_{2}$ dosage with regard to the photocatalytic degradation of RhB were optimized to be $7.5,500 \mathrm{mg} / \mathrm{L}$ and $8.9 \times 10^{-2} \mathrm{~mol} / \mathrm{L}$, respectively. In addition, visible light-induced photodegradation of $\mathrm{RhB}$ was also carried out by using $\mathrm{H}_{2} \mathrm{O}_{2}$ over a wide $\mathrm{pH}$ range in the absence of heterogeneous photocatalysts. It was observed that the reaction rate significantly increased above $\mathrm{pH} 10$, resulting in a faster rate of degradation of $\mathrm{RhB}$, which may be attributed to the deprotonation of hydrogen peroxide. Furthermore, the potential antibacterial property of such catalysts against the Gram-negative bacterium Vibrio fischeri in a bioluminescence assay yielded inhibition activities of more than $60 \%$ in all cases.
\end{abstract}

Keywords: heterogeneous photo-Fenton system, iron(II) doped copper ferrites, deprotonation effect, photodegradation

\section{Introduction}

Synthetic dyes have numerous applications in several industries, e.g., paper, textile, leather and paint. Besides these applications, some dyes are toxic organic compounds and their discharge into the environment causes eutrophication, aesthetic pollution and distress for marine organisms $[1,2]$. Some synthetic dyes are recalcitrant, that is, resistant to biological degradation and direct photolysis. In addition, many dyes contain nitrogen which produces carcinogenic as well as mutagenic aromatic amines as a result of natural anaerobic reductive degradation $[3,4]$.

These toxic organic dyes can be mineralized into water and carbon dioxide via photocatalytic reactions using catalysts under ultraviolet or visible light irradiation $[5,6]$. Only a handful of research groups have developed and applied ferrite nanoparticles (NPs) as catalysts which can utilize larger bandwidths of the visible light spectrum. Manganese ferrite [7], zinc ferrite [8-10], aluminium doped zinc ferrite [11], manganese doped cobalt ferrite [12], barium ferrite [13], copper ferrite [14], and nickel ferrites $[15,16]$ have been investigated with regard to the degradation of certain dyes and other toxic compounds.

\footnotetext{
*Correspondence: horvath.otto@mk.uni-pannon.hu
}

Our research group prepared and applied iron(II) doped copper ferrites $\mathrm{Cu}_{(x)}^{\mathrm{II}} \mathrm{Fe}_{(1-x)}^{\mathrm{II}} \mathrm{Fe}_{2}^{\mathrm{III}} \mathrm{O}_{4}$ (where $x=$ $0,0.2,0.4,0.6,0.8,1)$ for the photo-induced degradation of Methylene Blue (MB) [17]. Here, a detailed photocatalytic study on the degradation of Rhodamine $\mathrm{B}$ is presented by using heterogeneous photo-Fenton systems and compared to homogeneous photocatalytic procedures. In addition, the antibacterial property of iron(II) doped copper ferrites in the Vibrio scheri bioluminescence inhibition assay was investigated.

\section{Experimental}

\subsection{Materials}

Rhodamine B (molecular formula: $\mathrm{C}_{28} \mathrm{H}_{31} \mathrm{ClN}_{2} \mathrm{O}_{3}$ ) was used as a model dye for visible light-induced photocatalytic degradation. Anhydrous copper(II) sulfate, ferric chloride hexahydrate, ammonium iron(II) sulfate hexahydrate and sodium hydroxide were used to prepare the catalysts. Sodium hydroxide or hydrochloric acid was added to adjust the $\mathrm{pH}$ during photocatalysis. Hydrogen peroxide $(30 \% \mathrm{w} / \mathrm{w})$ was employed as Fenton's reagent and double distilled water used as a solvent throughout the study. All the laboratory-grade chemicals were obtained from Sigma-Aldrich (Budapest, Hungary) and used without further purification. 


\subsection{Applied catalysts}

The catalysts applied in this study were iron(II) doped copper ferrite $\mathrm{Cu}_{(x)}^{\mathrm{II}} \mathrm{Fe}_{(1-x)}^{\mathrm{II}} \mathrm{Fe}_{2}^{\mathrm{III}} \mathrm{O}_{4}$ NPs (where $x=0$ (NP-1), 0.2 (NP-2), 0.4 (NP-3), 0.6 (NP-4), 0.8 (NP$5), 1.0$ (NP-6)), which were prepared by a simple coprecipitation-calcination technique. The detailed methods for the synthesis of these catalysts and their structural elucidation have been reported in our earlier studies $[17,18]$.

\subsection{RhB photocatalytic reactions}

For photocatalysis, a stock solution of $0.5 \mathrm{~g} / \mathrm{L} \mathrm{RhB}$ was prepared. In order to perform the photocatalysis, a small cuvette used as a reactor was adjusted to a S600 UV/Vis diode array spectrophotometer. The concentration of $\mathrm{RhB}$ (approximately $1.8 \times 10^{-5} \mathrm{~mol} / \mathrm{L}$ ) in the cuvette was calculated by using the Beer-Lambert law [17].

Control experiments for the self-degradation of $\mathrm{RhB}$ were carried out without ferrite nanoparticles in the absence and presence of both light and hydrogen peroxide (for the oxidant effect). Then the NP catalyst of a given concentration was added to the RhB solution and stirred for 30 mins to ensure a good degree of dispersion and reach an adsorption equilibrium before photodegradation. The temperature of the photoreactor $\left(25 \pm 2{ }^{\circ} \mathrm{C}\right)$, concentration of $\mathrm{RhB}\left(1.8 \times 10^{-5} \mathrm{~mol} / \mathrm{L}\right)$ and duration (140 mins.) of photocatalytic experiments were kept constant. The process variables investigated were the catalyst dosage ( 80 to $800 \mathrm{mg} / \mathrm{L}$ ), hydrogen peroxide concentration $\left(2.2 \times 10^{-2}\right.$ to $\left.3.0 \times 10^{-1} \mathrm{~mol} / \mathrm{L}\right)$ and $\mathrm{pH}$ (2 to 12$)$. Meanwhile, the original $\mathrm{pH}$ of the total aqueous solution was approximately 7.5 . The $\mathrm{pH}$ was adjusted by adding $\mathrm{HCl}$ or $\mathrm{NaOH}$ before starting the photocatalytic experiment.

\subsection{Determination of reaction rate}

The Beer-Lambert law was used to determine the reaction rate of each experiment. The spectral changes observed in the visible range of the absorption spectrum (Fig. 1) indicate that the intermediates and end products formed during the photocatalytic degradation of RhB did not produce any remarkable peaks. Therefore, the reaction rate of $\mathrm{RhB}$ photodegradation can be determined from the reduction in absorbance at the maximum wavelength $\left(\lambda_{\max }=554 \mathrm{~nm}\right)$. The addition of heterogeneous photocatalysts caused the baseline in the recorded spectra to change as a consequence of scattering. This problem was resolved during the evaluation of the reaction rate by applying baseline corrections.

\subsection{Assessment of antibacterial property}

A Luminoskan Ascent microplate luminometer (Thermo Scientific) was used to measure the antibacterial property of the ferrite NPs in a Vibrio scheri bioluminescence

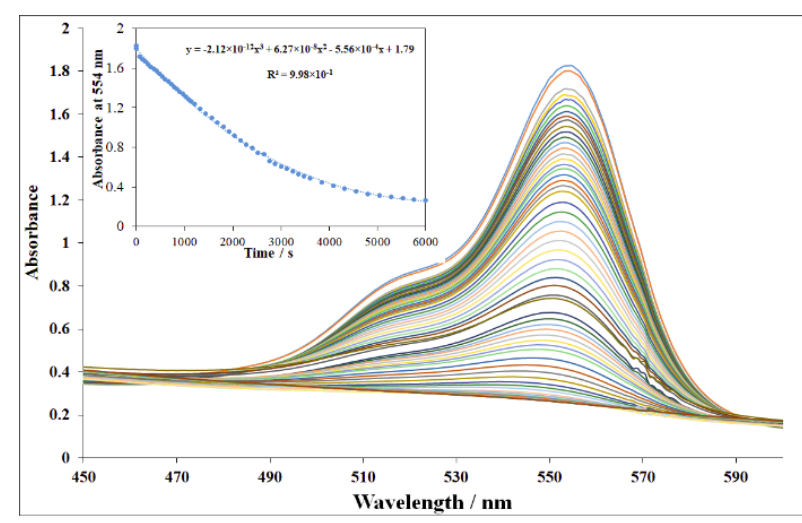

Figure 1: Spectral changes during Rhodamine B photodegradation in the presence of NP-3. The inset shows the absorbance vs. time plot at $554 \mathrm{~nm}$. Experimental conditions: concentration of RhB is $1.8 \times 10^{-5} \mathrm{~mol} / \mathrm{L}$, concentration of $\mathrm{H}_{2} \mathrm{O}_{2}$ is $1.8 \times 10^{-1} \mathrm{~mol} / \mathrm{L}$, concentration of $\mathrm{NP}-3$ is $400 \mathrm{mg} / \mathrm{L}$, initial $\mathrm{pH}$ is $=7.5$, and irradiation time is 140 mins.

inhibition assay. According to the manufacturer's (Hach Lange $\mathrm{GmbH}$, Germany) recommendations, a test specimen of a Gram-negative Vibrio fischeri (NRRL-B-11177) suspension was prepared with a lifespan of 4 hours after being reconstituted. The same test protocol was followed as reported in the literature [19].

During the evaluation, the results obtained from 2 parallel measurements were averaged before the relative inhibition (\%) was calculated using

$$
\text { Relative inhibition }(t)=\frac{I_{\mathrm{c}}(t)-I_{\mathrm{S}}(t)}{I_{\mathrm{c}}(t)} \times 100 \%
$$

where $I_{\mathrm{c}}(t)$ denotes the emission intensity of the control sample at time $t$ and $I_{\mathrm{S}}(t)$ represents the emission intensity of the test specimen at the same time.

\section{Results and discussion}

A detailed explanation regarding the control experiments concerning the photodegradation of $\mathrm{RhB}$ was reported in one of our previous studies [18]. The experiment used as a basis for comparisons ( $\mathrm{RhB}+\mathrm{H}_{2} \mathrm{O}_{2}+$ Light) is shown in Fig. 2.

After the control experiments, the photocatalytic efficiency of six doped ferrite nanoparticles was investigated. Fig. 1 shows the spectral changes obtained during the photocatalytic experiment using NP-3 and the decrease in the absorbance of $\mathrm{RhB}$ at $\lambda_{\max }=554 \mathrm{~nm}$ (inset of Fig. $1)$. The degradation reaction of $\mathrm{RhB}$ follows apparent rstorder kinetics (Fig. 3), which is also consistent with earlier observations regarding other catalysts $[20,21]$. The slight deviation from the straight line is due to the complex nature of this heterogeneous system.

Fig. 4 reveals that all doped ferrite NPs in the series of $\mathrm{Cu}_{(x)}^{\mathrm{II}} \mathrm{Fe}_{(1-x)}^{\mathrm{II}} \mathrm{Fe}_{2}^{\mathrm{III}} \mathrm{O}_{4}(x=0-1)$ delivered higher apparent rate constants for the degradation of RhB compared to the control experiment. Doped copper ferrites 


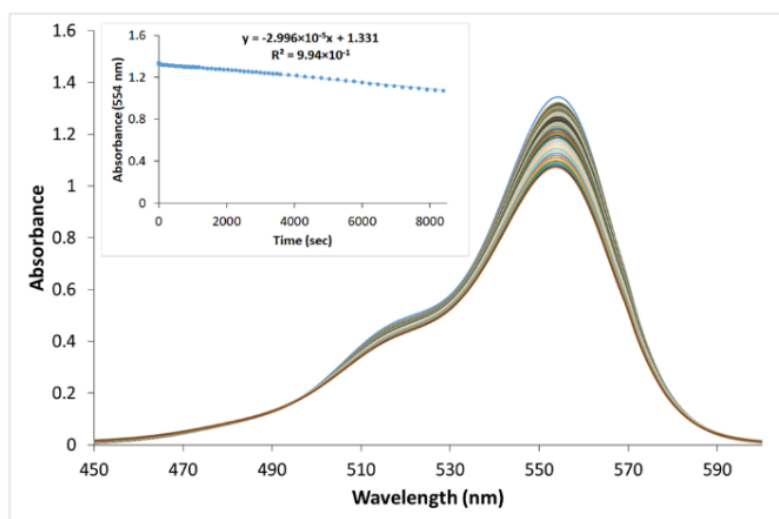

Figure 2: Spectral changes during the photodegradation of Rhodamine B in the absence of NPs. The inset shows the absorbance vs. time plot at $\lambda_{\max }=554 \mathrm{~nm}$. Experimental conditions: concentration of $\mathrm{H}_{2} \mathrm{O}_{2}$ is $1.8 \times 10^{-1} \mathrm{~mol} / \mathrm{L}$, concentration of $\mathrm{RhB}$ is $1.8 \times 10^{-5} \mathrm{~mol} / \mathrm{L}$, and irradiation time is 140 mins.

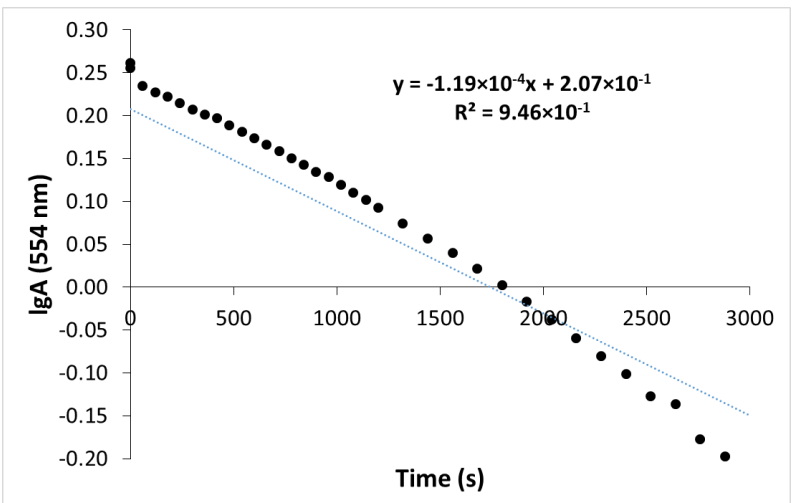

Figure 3: A plot of the logarithm of the absorbance at 554 $\mathrm{nm}$ vs. time for the photodegradation of $\mathrm{RhB}$ (see the inset of Fig. 1)

NP-2 and NP-3 exhibited outstanding photocatalytic performances in the series studied. Nickel doped cobalt ferrite NPs revealed a very similar trend with regard to the photo-oxidative degradation of RhB [22]. The higher apparent rate constants for the degradation of $\mathrm{RhB}$ using NP-2 and NP-3 may be attributed to their special needlelike crystalline structure [17]. On the basis of the first experimental series, NP-3 was chosen to further investigate three important determinants, namely the catalyst dosage, hydrogen peroxide concentration and $\mathrm{pH}$ of the heterogeneous photo-Fenton system.

\subsection{The effect of catalyst dosage}

Fig. 5 shows the effect of the NP-3 dosage $(0-800 \mathrm{mg} / \mathrm{L})$ on the apparent rate constant. The increase in dosage from $0-500 \mathrm{mg} / \mathrm{L}$ yielded a significant increase in the apparent rate constant. This phenomenon can be attributed to the higher number of available active sites in heterogeneous photo-Fenton processes [23]. However, increasing the dosage of NPs above $500 \mathrm{mg} / \mathrm{L}$ caused a moderate

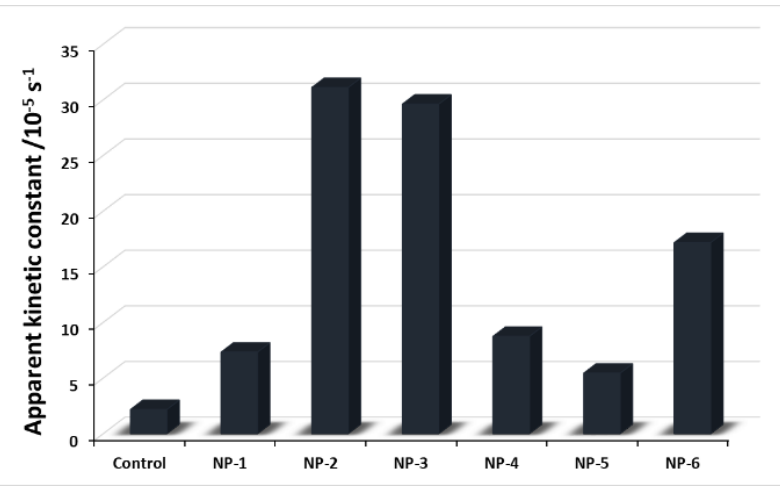

Figure 4: Photocatalytic efficiency in terms of apparent rate constants (compared to the control experiment) for NP-1 to 6. Experimental conditions: concentration of NPs is $400 \mathrm{mg} / \mathrm{L}$, concentration of $\mathrm{RhB}$ is $1.8 \times 10^{-5} \mathrm{~mol} / \mathrm{L}$, concentration of $\mathrm{H}_{2} \mathrm{O}_{2}$ is $1.8 \times 10^{-1} \mathrm{~mol} / \mathrm{L}$, initial $\mathrm{pH}$ is 7.5 , and irradiation time is $140 \mathrm{mins}$.

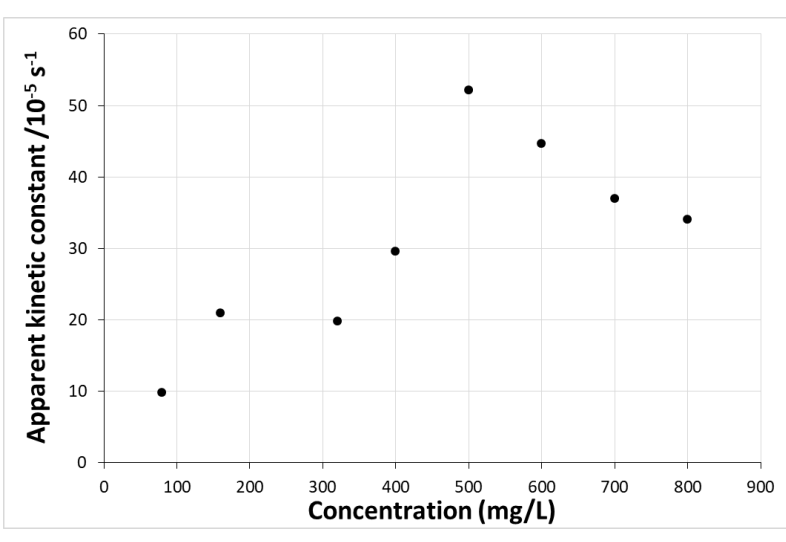

Figure 5: Effect of the concentration of NP-3 on the apparent rate constant of $\mathrm{RhB}$ photodegradation. Experimental conditions: concentration of $\mathrm{RhB}$ is $1.8 \times 10^{-5} \mathrm{~mol} / \mathrm{L}$, concentration of $\mathrm{H}_{2} \mathrm{O}_{2}$ is $1.8 \times 10^{-1} \mathrm{~mol} / \mathrm{L}$, initial $\mathrm{pH}$ is 7.5 , and irradiation time is 140 mins.

decrease in the apparent rate constant, which may be attributed to the fact that higher concentrations of NPs can increase the turbidity of the reaction system, thereby hindering the absorption of light [4]. Therefore, for the photocatalytic experiments that followed, an optimum NP-3 dosage of $500 \mathrm{mg} / \mathrm{L}$ was used.

\subsection{The effect of the hydrogen peroxide con- centration}

At first, the effect of $\mathrm{H}_{2} \mathrm{O}_{2}$ on the photodegradation of $\mathrm{RhB}$ in the absence of NPs was investigated (Fig. 6). The concentration of $\mathrm{H}_{2} \mathrm{O}_{2}$ was increased from $4.5 \times 10^{-2}$ to $6.7 \times 10^{-1} \mathrm{~mol} / \mathrm{L}$. The reaction rate was enhanced by increasing the concentration of $\mathrm{H}_{2} \mathrm{O}_{2}$ up to $3.5 \times 10^{-1}$ $\mathrm{mol} / \mathrm{L}$. However, beyond this value, a slight decrease in the apparent rate constant was observed.

The second experimental series focused on checking the effect of increasing the concentration of $\mathrm{H}_{2} \mathrm{O}_{2}$ from $2.2 \times 10^{-2}$ to $3 \times 10^{-1} \mathrm{~mol} / \mathrm{L}$ in the presence of NPs 


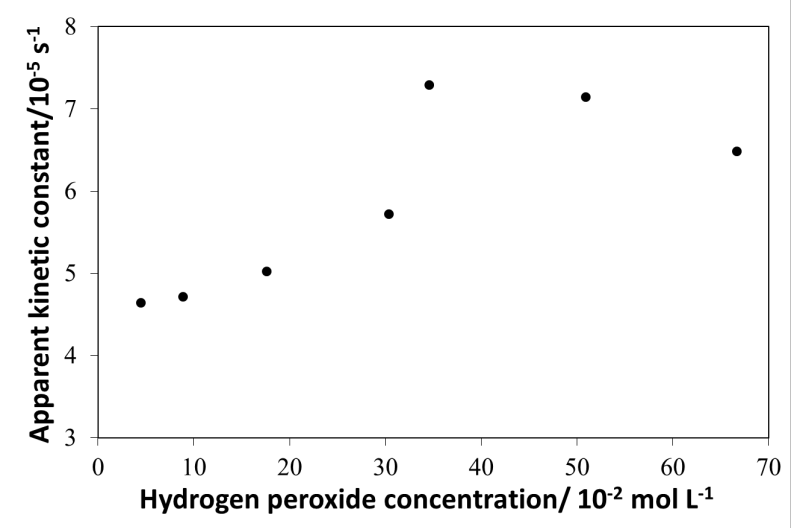

Figure 6: Effect of the concentration of $\mathrm{H}_{2} \mathrm{O}_{2}$ on the apparent rate constant of $\mathrm{RhB}$ photodegradation in the absence of NPs. Experimental conditions: concentration of $\mathrm{RhB}$ is $1.8 \times 10^{-5} \mathrm{~mol} / \mathrm{L}$, initial $\mathrm{pH}$ is 7.5 , and irradiation time is 140 mins.

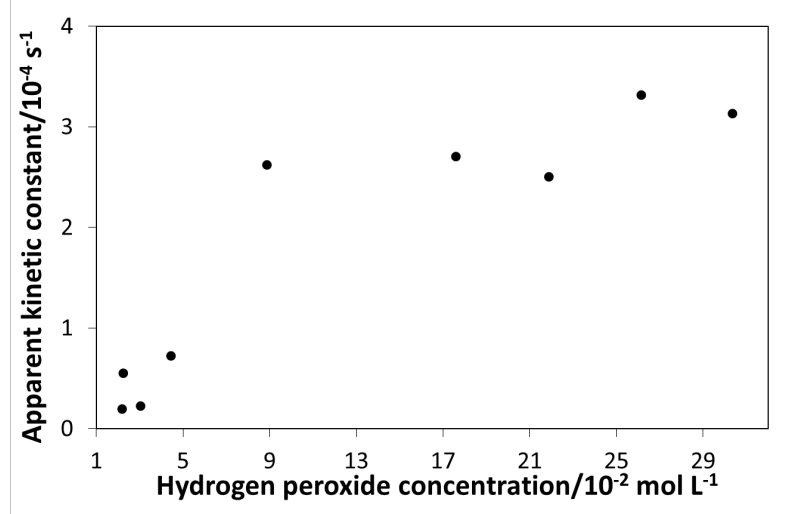

Figure 7: Effect of the concentration of $\mathrm{H}_{2} \mathrm{O}_{2}$ on the apparent rate constant of $\mathrm{RhB}$ photodegradation in the presence of NP-3 in a heterogeneous photo-Fenton system. Experimental conditions: concentration of $\mathrm{RhB}$ is $1.8 \times 10^{-5}$ $\mathrm{mol} / \mathrm{L}$, concentration of $\mathrm{NP}-3$ is $500 \mathrm{mg} / \mathrm{L}$, initial $\mathrm{pH}$ is 7.5 , and irradiation time is 140 mins.

in a heterogeneous photo-Fenton system (Fig. 7). The reaction rate was remarkably improved by increasing the concentration of $\mathrm{H}_{2} \mathrm{O}_{2}$ up to $8.9 \times 10^{-2} \mathrm{~mol} / \mathrm{L}$. A further increase in the concentration of $\mathrm{H}_{2} \mathrm{O}_{2}$ did not enhance the reaction rate significantly, moreover, similar results have been published in the literature [24,25]. The excess $\mathrm{H}_{2} \mathrm{O}_{2}$ could act as a ${ }^{\bullet} \mathrm{OH}$ scavenger, producing the less reactive $\mathrm{HO}_{2}^{\bullet}$ species instead of the highly potent ${ }^{\bullet} \mathrm{OH}[4,23,25]$. Hence $8.9 \times 10^{-2} \mathrm{~mol} / \mathrm{L}$ as an optimum concentration of $\mathrm{H}_{2} \mathrm{O}_{2}$ was used in experiments on the photocatalytic degradation of $\mathrm{RhB}$ that followed.

\subsection{The effect of $\mathrm{pH}$}

The surface charge properties of the photocatalyst and the ionic species present in the photocatalytic reactor are greatly influenced by the $\mathrm{pH}$. Furthermore, the photodegradation efficiency of the dye is affected by the ionic

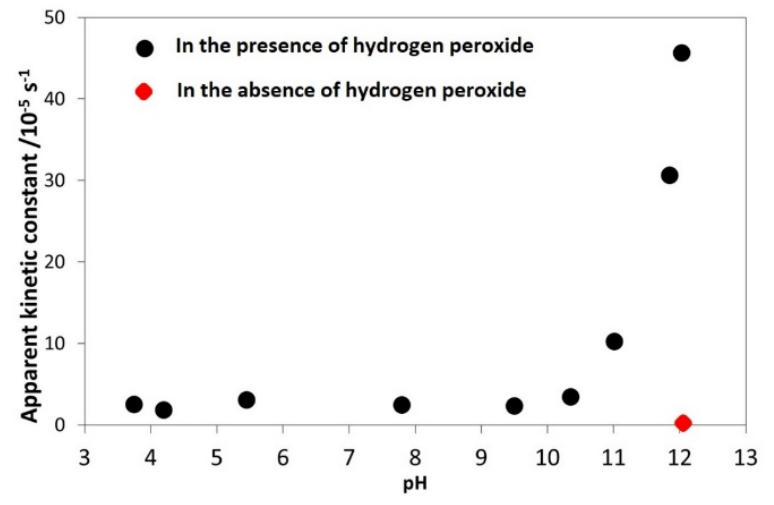

Figure 8: Effect of the initial $\mathrm{pH}$ on the apparent rate constant of RhB photodegradation in the absence of NPs. Experimental conditions: concentration of $\mathrm{RhB}$ is $1.8 \times 10^{-5}$ $\mathrm{mol} / \mathrm{L}$, concentration of $\mathrm{H}_{2} \mathrm{O}_{2}$ is $8.9 \times 10^{-2} \mathrm{~mol} / \mathrm{L}$, and irradiation time is $140 \mathrm{mins}$.

species and surface charge of the photocatalyst in the reaction mixture. Two experimental series were designed to study the effect of $\mathrm{pH}$ on the visible light-induced degradation of RhB. In the first series, the $\mathrm{pH}$ was varied from 3.8 to 12.1 while the concentrations of $\mathrm{RhB}$ and $\mathrm{H}_{2} \mathrm{O}_{2}$ were kept constant in the absence of NPs. Remarkably, neutral and alkaline $\mathrm{pHs}$ were found to be more effective in this system concerning $\mathrm{RhB}$ photodegradation (Fig. 8). In addition, the presence and absence of $\mathrm{H}_{2} \mathrm{O}_{2}$ were also investigated at higher $\mathrm{pH}$ values (approximately $\mathrm{pH} 12$ ), which can be seen from the last two data points in Fig. 8. It was observed that significantly enhancing the fraction of the more reactive deprotonated form of hydrogen peroxide $\left(\mathrm{HO}_{2}^{-}\right)$at higher $\mathrm{pH}$ values $(\mathrm{pKa}=11.75$ [26]) noticeably accelerated the rate of RhB degradation. On the basis of Fig. 8, it was possible to determine the individual (apparent) rate constants (under these conditions) for the differently protonated forms of peroxide, namely $1.9 \times 10^{-5} \mathrm{~s}^{-1}$ for $\mathrm{H}_{2} \mathrm{O}_{2}$ and $6.2 \times 10^{-4} \mathrm{~s}^{-1}$ for $\mathrm{HO}_{2}^{-}$. Deprotonation resulted in increasing the degradation effect by 32 times.

Moreover, the effect of the $\mathrm{pH}$ in the presence of NPs (Fig. 9) revealed that a neutral or near alkaline $\mathrm{pH}$ could be optimal during this type of reaction. Although the best apparent rate constant was observed at $\mathrm{pH} \approx 8$, further increasing the $\mathrm{pH}$ resulted in a slight decrease in the reaction rate. By comparing Figs. 8 and 9, it can be observed that the partly hydroxylated forms of the metal ions $\left(\left[\mathrm{Fe}^{\mathrm{III}}(\mathrm{OH})_{2}\right]^{+},\left[\mathrm{Cu}^{\mathrm{II}}(\mathrm{OH})\right]^{+}\right)$could also be identified at the local maximum of approximately $\mathrm{pH}=8$ presented in Fig. 9. Therefore, the partly hydroxylated metal ions can react with $\mathrm{H}_{2} \mathrm{O}_{2}$, resulting in $\mathrm{a} \approx 14$ times increase in the individual (apparent) rate constant $\left(2.7 \times 10^{-4} \mathrm{~s}^{-1}\right.$ compared to $1.9 \times 10^{-5} \mathrm{~s}^{-1}$ for $\mathrm{H}_{2} \mathrm{O}_{2}$ in the absence of NPs).

The $\mathrm{pH}$ can also alter the charge state of $\mathrm{RhB}$ in the reaction mixture. Furthermore, at high $\mathrm{pH}$ values, $\mathrm{RhB}$ aggregates are produced as a result of the excessive concen- 


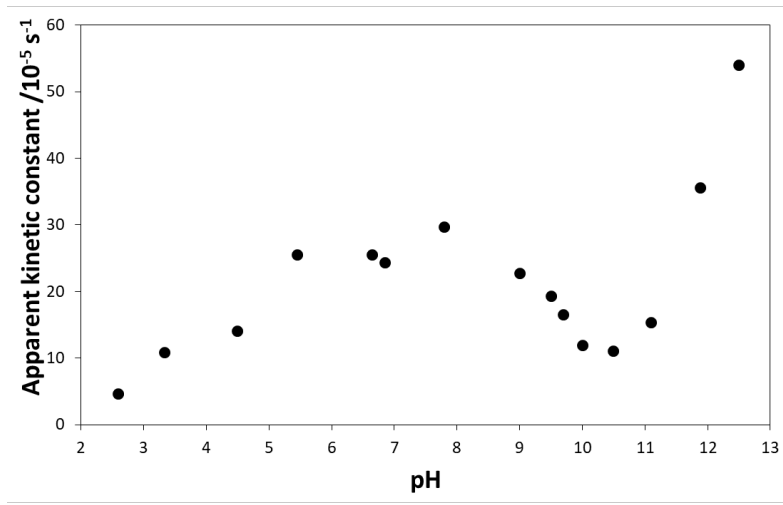

Figure 9: Effect of the $\mathrm{pH}$ on the apparent rate constant of $\mathrm{RhB}$ photodegradation in the presence of NP-3 in a heterogeneous system. Experimental conditions: concentration of NP-3 is $500 \mathrm{mg} / \mathrm{L}$, concentration of $\mathrm{RhB}$ is $1.8 \times 10^{-5}$ $\mathrm{mol} / \mathrm{L}$, concentration of $\mathrm{H}_{2} \mathrm{O}_{2}$ is $8.9 \times 10^{-2} \mathrm{~mol} / \mathrm{L}$, and irradiation time is 140 mins.

tration of $\mathrm{OH}^{-}$ions, which compete with $\mathrm{COO}^{-}$to bind with $-\mathrm{N}^{+}$. In addition, since the surface of the solid catalyst is negatively charged, it repels the $\mathrm{RhB}$ due to the presence of ionic $\mathrm{COO}^{-}$groups under basic conditions. Therefore, the degradation efficiency on the surface of the photocatalyst is decreased. The same phenomenon in the case of bismuth ferrite nanoparticles has been reported in the literature $[4,27]$. However, an increase in the $\mathrm{pH}$ above 11 significantly enhanced the reaction rate (Fig. 9) in a very similar manner to the reaction in the absence of NPs. As a result, the presence of NPs does not further increase the reactivity of $\mathrm{HO}_{2}^{-}$.

In addition, the effect of light, hydrogen peroxide and NPs at an approximately constant $\mathrm{pH}$ is illustrated in Table 1 . The light-induced degradation of $\mathrm{RhB}$ at $\mathrm{pH} 12$ in the absence of both hydrogen peroxide and NP-3 yielded a very low reaction rate (Step 1). In Step 2, the addition of hydrogen peroxide in the absence of both light and NP-3 at pH 11.9 yielded a faster reaction rate. Step 3, which represents a heterogeneous Fenton system, yielded a much faster reaction rate. The heterogeneous photoFenton system shown in Step 4 yielded the best reaction rate as far as the degradation of $\mathrm{RhB}$ is concerned.

The catalyst NP-3 $\left(\mathrm{Cu}_{(0.4)}^{\mathrm{II}} \mathrm{Fe}_{(0.6)}^{\mathrm{II}} \mathrm{Fe}_{2}^{\mathrm{III}} \mathrm{O}_{4}\right)$ was able to overcome the disadvantage of the narrow $\mathrm{pH}$ range of conventional photo-Fenton processes. Based on this experimental series, the catalyst $\mathrm{Cu}_{(0.4)}^{\mathrm{II}} \mathrm{Fe}_{(0.6)}^{\mathrm{II}} \mathrm{Fe}_{2}^{\mathrm{III}} \mathrm{O}_{4}$ is a promising candidate for the degradation of various recalcitrant dyes.

\subsection{Generalized RhB degradation mecha- nism}

A very simple schematic mechanism is proposed for the purpose of $\mathrm{RhB}$ degradation since the reactive species produced during irradiation, namely ${ }^{\bullet} \mathrm{OH}, \mathrm{H}^{+}$and ${ }^{\bullet} \mathrm{O}_{2}^{-}$, oxidize $\mathrm{RhB}$ molecules to intermediates of lower molecular weights. Generally speaking, the active species react

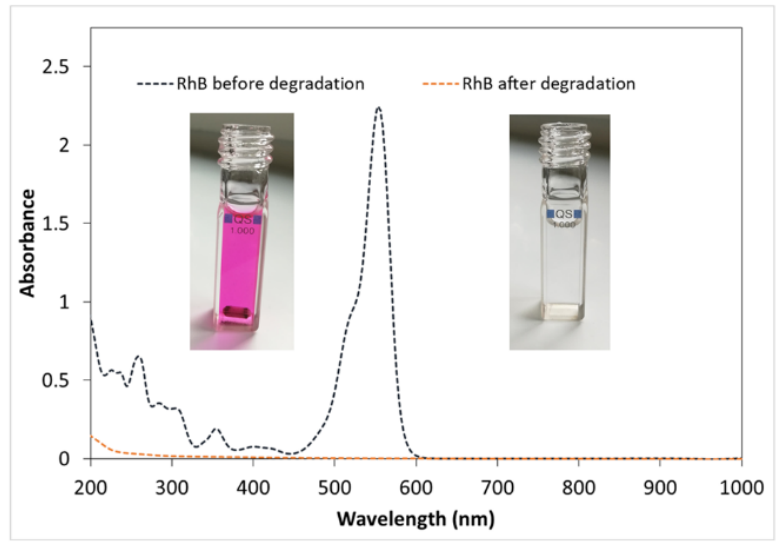

Figure 10: Visual and spectrometric comparison of $\mathrm{RhB}$ before and after its degradation; experimental conditions: concentration of NPs is $500 \mathrm{mg} / \mathrm{L}$, concentration of $\mathrm{RhB}$ is $1.8 \times 10^{-5} \mathrm{~mol} / \mathrm{L}$, concentration of $\mathrm{H}_{2} \mathrm{O}_{2}$ is $8.9 \times 10^{-2}$ $\mathrm{mol} / \mathrm{L}$, and irradiation time is 140 mins.

with the central carbon atom in the chemical structure of $\mathrm{RhB}$. Then the oxidizing agents attack the intermediates produced in the previous step, yielding smaller open-ring compounds. Subsequently, the latter compounds are mineralized to water and carbon dioxide [28]. As is displayed in Fig. 10, the UV/visible absorption spectrum of RhB degradation yields prominent peaks at 262, 358 and 554 $\mathrm{nm}$. However, no significant peaks were observed following photodegradation (Fig. 10) in neither the visible nor UV region, which confirmed the complete mineralization of RhB.

The images obtained from the photoreactor (cuvette) before and after photocatalysis also confirmed the complete degradation of $\mathrm{RhB}$, namely a clear, colorless solution was obtained after the removal of solid catalysts (Fig. 10) by centrifugal filtration.

\subsection{Photocatalytic efficiencies under opti- mized conditions}

Finally, the photocatalytic efficiencies of all six NPs (NP1 to 6$)$ were determined under optimized conditions for the degradation of RhB (Fig. 11). It was observed that all of the NPs were active photocatalysts, the application of NP-3 yielded the highest reaction rate. These results are quite comparable to those presented in Fig. 4 obtained from the first series of experiments. However, the concentration of hydrogen peroxide under the optimized conditions $\left(8.9 \times 10^{-2} \mathrm{~mol} / \mathrm{L}\right)$ is considerably lower than in the first series $\left(1.8 \times 10^{-1} \mathrm{~mol} / \mathrm{L}\right)$ and is, therefore, much more economical. Although the concentration of the photocatalyst is higher under the optimized conditions (500 vs. $400 \mathrm{mg} / \mathrm{L}$ ), the NPs can be reused over several cycles. According to our results, all NPs in the series can potentially be applied for the purpose of environmental remediation. 
Table 1: Comparison of the reaction rate and apparent rate constant at $\mathrm{pH} \approx 12$ in homogeneous (Steps $1 \& 2$ ) and heterogeneous (Steps 3 \& 4) systems.

\begin{tabular}{|c|c|c|c|c|c|c|c|}
\hline Step No. & Light & $\begin{array}{l}\text { Hydrogen peroxide } \\
\qquad(\mathrm{mol} / \mathrm{L})\end{array}$ & NP-3 (mg/L) & $\begin{array}{c}\text { Initial } \mathrm{pH} \\
\text { by adding } \mathbf{1 5} \\
\mu \mathrm{L} 1 \mathrm{M} \mathrm{NaOH})\end{array}$ & Final $\mathrm{pH}$ & $\begin{array}{c}\text { Apparent } \\
\text { rate constant }(1 / \mathrm{s})\end{array}$ & $\begin{array}{c}\text { Comparison } \\
\text { with basic } \\
\text { reaction (\%) }\end{array}$ \\
\hline 1 & visible & 0 & 0 & 12.1 & 11.7 & $2.6 \times 10^{-6}$ & 12 \\
\hline 2 & no & $8.9 \times 10^{-2}$ & 0 & 11.9 & 11 & $1.6 \times 10^{-4}$ & 749 \\
\hline 3 & no & $8.9 \times 10^{-2}$ & 500 & 11.9 & 11.3 & $2.7 \times 10^{-4}$ & 1256 \\
\hline 4 & visible & $8.9 \times 10^{-2}$ & 500 & 11.9 & 11.2 & $3.6 \times 10^{-4}$ & 1642 \\
\hline
\end{tabular}

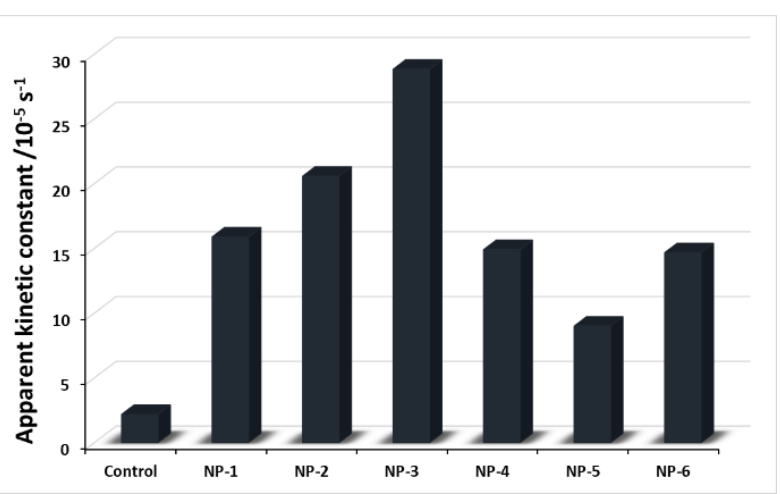

Figure 11: Photocatalytic efficiency in terms of apparent rate constants (compared to the control experiment) for NP-1 to 6. Experimental conditions: concentration of NPs is $500 \mathrm{mg} / \mathrm{L}$, concentration of $\mathrm{RhB}$ is $1.8 \times 10^{-5} \mathrm{~mol} / \mathrm{L}$, concentration of $\mathrm{H}_{2} \mathrm{O}_{2}$ is $8.9 \times 10^{-2} \mathrm{~mol} / \mathrm{L}$, initial $\mathrm{pH}$ is 7.5 , and irradiation time is 140 mins.

\subsection{Assessment of the antibacterial activity of doped copper ferrites}

The inhibition effect $(\%)$ of doped copper ferrites against Gram-negative Vibrio scheri in bioluminescence assays is illustrated in Fig. 12. The inhibition (\%) of bacteria in the presence of doped nanoparticles containing varying ratios of copper $\left(\mathrm{Cu}^{\mathrm{II}}\right)$ and iron $\left(\mathrm{Fe}^{\mathrm{II}}\right)$ revealed that all doped copper ferrites yielded sufficient antibacterial activities. In our research, higher ratios of $\mathrm{Cu}^{\mathrm{II}}$ proved to be useful in improving antibacterial activity. The same trend in terms of bacterial inhibition against Gram-negative Escherichia coli was observed using cobalt ferrite nanoparticles synthesized by co-precipitation [29].

Generally speaking, $\mathrm{Cu}^{\mathrm{II}}$ can disrupt the functions of cells in several ways, hence the ability of microorganisms to develop resistance to $\mathrm{Cu}^{\mathrm{II}}$ is remarkably reduced. The attachment of $\mathrm{Cu}^{\mathrm{II}}$ ions to the surface of microorganisms plays a key role in their antibacterial activity [30]. The ions from the surface of doped copper ferrites, especially $\mathrm{Cu}^{\mathrm{II}}$, are adsorbed onto bacterial cell walls, damaging the cell membrane in two possible ways, namely by altering the functions of enzymes or solidifying the structures of proteins. Therefore, the presence of copper ferrites in the bacterial growth medium immobilizes and inactivates bacteria, inhibiting their ability to replicate and ultimately leading to cell death [31].

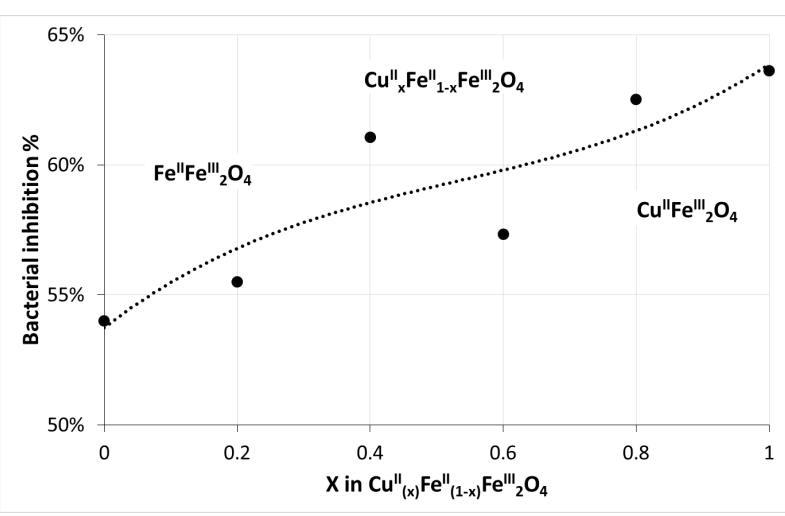

Figure 12: Comparison of the degree of bacterial inhibition using doped copper ferrites against Gram-negative Vibrio scheri.

In our study, a mechanism is proposed (Fig. 13) in which doped copper ferrites are attached to the cell wall of the bacterium Vibrio fischeri, reducing its ability to replicate. The degree of bacterial inhibition in all cases is approximately $60 \%$, which confirms the potential application of doped copper ferrites in terms of antibacterial developments.

\section{Conclusion}

Iron(II) doped copper ferrites $\mathrm{Cu}_{(x)}^{\mathrm{II}} \mathrm{Fe}_{(1-x)}^{\mathrm{II}} \mathrm{Fe}_{2}^{\mathrm{III}} \mathrm{O}_{4}$ have been proven to be efficient catalysts for the degradation of organic pollutants under visible-light irradiation in the presence of hydrogen peroxide. The performances of NPs with copper(II) ratios of $x=0.2$ and 0.4 were especially promising under optimized conditions. Contrary to conventional homogeneous photo-Fenton systems, our catalysts exhibit higher efficiencies under neutral and near alkaline conditions. Besides their advantageous photocatalytic ability, these NPs also show a sufficient degree of antibacterial activity, due to their copper(II) constituents. By taking both properties into consideration, $\mathrm{Cu}_{(0.4)}^{\mathrm{II}} \mathrm{Fe}_{(0.6)}^{\mathrm{II}} \mathrm{Fe}_{2}^{\mathrm{III}} \mathrm{O}_{4}$ yields the optimum combination of these features. Therefore, from the series of NPs studied in this work, NP-3 is the most promising candidate for the combined photocatalytic purification and disinfection of water. 
(A)

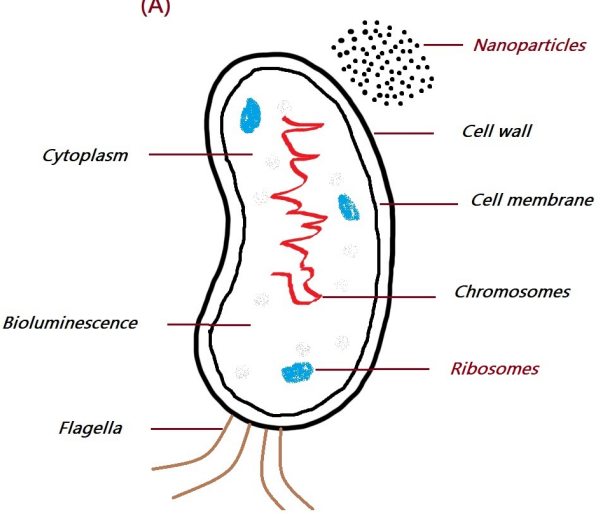

(B)

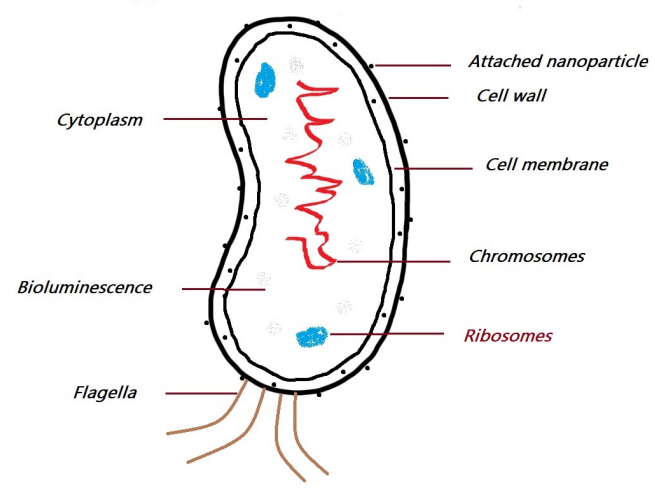

Figure 13: Proposed mechanism for the attachment of nanoparticles to Vibrio fischeri: bacterium and nanoparticles before (A) and after (B) attachment.

\section{Acknowledgments}

The proficient support of Prof. Dr. Éva Kristóf-Makó, Prof. Dr. Kristóf Kovács and Dr. Balázs Zsirka in terms of the structural elucidation of nanoparticle catalysts is gratefully acknowledged. This work was supported by the National Research, Development and Innovation Office of Hungary in the framework of the bilateral Hungarian-French science and technology (S\&T) cooperation project 2019-2.1.11-TÉT-2019-00033).

\section{Declaration of interest}

The authors declare that they have no known competing financial interests or personal relationships that may have appeared to influence the work reported in this paper.

\section{REFERENCES}

[1] Bao, N.; Feng, X.; Yang, Z.; Shen, L.; Lu, X.: Highly efficient liquid-phase photooxidation of an azo dye methyl orange over novel nanostructured porous titanate-based fiber of self-supported radially aligned $\mathrm{H}_{2} \mathrm{Ti}_{8} \mathrm{O}_{17} \cdot 1.5 \mathrm{H}_{2} \mathrm{O}$ Nanorods. Environ. Sci. Technol., 2004, 38(9), 2729-2736 DOI: 10.1021/es034388k

[2] Abdi, J.; Yahyanezhad, M.; Sakhaie, S.; Vossoughi, M.; Alemzadeh, I.: Synthesis of porous $\mathrm{TiO}_{2} / \mathrm{ZrO}_{2}$ photocatalyst derived from zirconium metal organic framework for degradation of organic pollutants under visible light irradiation. J. Environ. Chem. Eng., 2019, 7(3), 103096 DOI: 10.1016/j.jece.2019.103096

[3] Horikoshi, S.; Hojo, F.; Hidaka, H.; Serpone, N.: Environmental remediation by an integrated microwave/UV illumination technique. 8. Fate of carboxylic acids, aldehydes, alkoxycarbonyl and phenolic substrates in a microwave radiation field in the presence of $\mathrm{TiO}_{2}$ particles under $\mathrm{UV}$ irradiation. Environ. Sci. Technol., 2004, 38(7), 2198-2208 DOI: 10.1021/es034823a
[4] Guo, S.; Zhang, G.; Jimmy, C. Y.: Enhanced photoFenton degradation of rhodamine $\mathrm{B}$ using graphene oxide-amorphous $\mathrm{FePO}_{4}$ as effective and stable heterogeneous catalyst. J. Colloid Interface Sci., 2015, 448, 460-466 DOI: 10.1016/j.jcis.2015.02.005

[5] Huang, Y.; Li, J.; Ma, W.; Cheng, M.; Zhao, J.; Yu, J. C.: Efficient $\mathrm{H}_{2} \mathrm{O}_{2}$ oxidation of organic pollutants catalyzed by supported iron sulfophenylporphyrin under visible light irradiation. J. Phys. Chem. B., 2004, 108(22), 7263-7270 DOI: 10.1021/jp036054n

[6] Dhiwahar, A. T.; Maruthamuthu, S.; Marnadu, R.; Sundararajan, M.; Manthrammel, M. A.; Shkir, M.; Sakthivel, P.; Reddy, V. R. M.: Improved photocatalytic degradation of rhodamine $\mathrm{B}$ under visible light and magnetic properties using microwave combustion grown $\mathrm{Ni}$ doped copper ferrite spinel nanoparticles. Solid State Sci., 2021, 113, 106542 DOI: 10.1016/j.solidstatesciences.2021.106542

[7] Luciano, A. J. R.; de Sousa Soletti, L.; Ferreira, M. E. C.; Cusioli, L. F.; de Andrade, M. B.; Bergamasco, R.; Yamaguchi, N. U.: Manganese ferrite dispersed over graphene sand composite for methylene blue photocatalytic degradation. $J$. Environ. Chem. Eng., 2020, 8(5), 104191 DOI: 10.1016/j.jece.2020.104191

[8] Mandal, S.; Natarajan, S.; Tamilselvi, A.; Mayadevi, S.: Photocatalytic and antimicrobial activities of zinc ferrite nanoparticles synthesized through soft chemical route: A magnetically recyclable catalyst for water/wastewater treatment. $J$. Environ. Chem. Eng., 2016, 4(3), 2706-2712 DOI: 10.1016/j.jece.2016.05.020

[9] Mahmoodi, N. M.: Zinc ferrite nanoparticle as a magnetic catalyst: synthesis and dye degradation. Mater. Res. Bull., 2013, 48(10), 4255-4260 DOI: 10.1016/j.materresbull.2013.06.070

[10] Han, L.; Zhou, X.; Wan, L.; Deng, Y.; Zhan, S.: Synthesis of $\mathrm{ZnFe}_{2} \mathrm{O}_{4}$ nanoplates by succinic acidassisted hydrothermal route and their photocatalytic degradation of rhodamine B under visible light. 
J. Environ. Chem. Eng., 2014, 2(1), 123-130 DOI: 10.1016/j.jmrt.2020.10.080

[11] Borhan, A. I.; Samoila, P.; Hulea, V.; Iordan, A. R.; Palamaru, M. N.: Effect of $\mathrm{Al}^{3+}$ substituted zinc ferrite on photocatalytic degradation of Orange I azo dye. J. Photochem. Photobiol. A Chem., 2014, 279, 17-23 DOI: 10.1016/j.jphotochem.2014.01.010

[12] Dou, R.; Cheng, H.; Ma, J.; Komarneni, S.: Manganese doped magnetic cobalt ferrite nanoparticles for dye degradation via a novel heterogeneous chemical catalysis. Mater. Chem. Phys., 2020, 240, 122181 DOI: $10.1016 /$ j.matchemphys.2019.122181

[13] Roonasi, P.; Mazinani, M.: Synthesis and application of barium ferrite/activated carbon composite as an effective solar photocatalyst for discoloration of organic dye contaminants in wastewater. J. Environ. Chem. Eng., 2017, 5(4), 3822-3827 DOI: 10.1016/j.jece.2017.07.035

[14] Tehrani-Bagha, A.; Gharagozlou, M.; Emami, F.: Catalytic wet peroxide oxidation of a reactive dye by magnetic copper ferrite nanoparticles. J. Environ. Chem. Eng., 2016, 4(2), 1530-1536 DOI: 10.1016/j.jece.2016.02.014

[15] Goyal, A.; Bansal, S.; Singhal, S.: Facile reduction of nitrophenols: Comparative catalytic efficiency of $\mathrm{MFe}_{2} \mathrm{O}_{4}(\mathrm{M}=\mathrm{Ni}, \mathrm{Cu}, \mathrm{Zn})$ nano ferrites. Int. J. Hydrog. Energy, 2014, 39(10), 4895-4908 DOI: 10.1016/j.ijhydene.2014.01.050

[16] Liu, S. Q.; Feng, L. R.; Xu, N.; Chen, Z. G.; Wang, X. M.: Magnetic nickel ferrite as a heterogeneous photo-Fenton catalyst for the degradation of rhodamine $\mathrm{B}$ in the presence of oxalic acid. Chem. Eng. Technol., 2012, 203, 432-439 DOI: 10.1016/j.cej.2012.07.071

[17] Khan, A.; Valicsek, Z.; Horváth, O.: Synthesis, characterization and application of iron (II) doped copper ferrites $\left(\mathrm{Cu}_{(x)}^{\mathrm{II}} \mathrm{Fe}_{(1-x)}^{\mathrm{II}} \mathrm{Fe}_{2}^{\mathrm{III}} \mathrm{O}_{4}\right)$ as novel heterogeneous photo-Fenton catalysts. Nanomaterials, 2020, 10(5), 921 DOI: 10.3390/nano10050921

[18] Khan, A.; Valicsek, Z.; Horváth, O.: Comparing the degradation potential of copper (II), iron (II), iron (III) oxides, and their composite nanoparticles in a heterogeneous photo-Fenton system. Nanomaterials, 2021, 11(1), 225 DOI: 10.3390/nano11010225

[19] Szabó-Bárdos, E.; Kulcsár, P.; Kováts, N.; Békéssy, Z.; Eck-Varanka, B.; Horváth, O.: Assessment of the potential bactericide effect of self-cleaning floors: a proposed protocol. Luminescence, 2020, 35(3), 434-436 DOI: 10.1002/bio.3745

[20] Li, Y. F.; Xu, D.; Oh, J. I.; Shen, W.; Li, X.; Yu, Y.: Mechanistic study of codoped titania with nonmetal and metal ions: a case of $\mathrm{C}+\mathrm{Mo}$ codoped $\mathrm{TiO}_{2}$. ACS Catal., 2012, 2(3), 391-398 DOI: 10.1021/cs2006668

[21] Rahman, Q. I.; Ahmad, M.; Misra, S. K.; Lohani, M.: Effective photocatalytic degradation of rhodamine B dye by $\mathrm{ZnO}$ nanoparticles. Mater. Lett., 2013, 91, 170-174 DOI: 10.1016/j.matlet.2012.09.044
[22] Singh, C.; Goyal, A.; Singhal, S.: Nickel-doped cobalt ferrite nanoparticles: efficient catalysts for the reduction of nitroaromatic compounds and photo-oxidative degradation of toxic dyes. Nanoscale, 2014, 6(14), 7959-7970 DOI: 10.1039/C4NR01730G

[23] Wang, X.; Pan, Y.; Zhu, Z.; Wu, J.: Efficient degradation of rhodamine $\mathrm{B}$ using $\mathrm{Fe}$ based metallic glass catalyst by Fenton-like process. Chemosphere, 2014, 117, 638-643 DOI: 0.1016/j.chemosphere.2014.09.055

[24] Zhang, L.; Nie, Y.; Hu, C.; Qu, J.: Enhanced Fenton degradation of Rhodamine $\mathrm{B}$ over nanoscaled $\mathrm{Cu}$ doped $\mathrm{LaTiO}_{3}$ perovskite. Appl. Catal. B Environ., 2012, 125, 418-424 DOI: 10.1016/j.apcatb.2012.06.015

[25] Salem, M. A.; Abdel-Halim, S. T.; El-Sawy, A. E.-H. M.; Zaki, A. B.: Kinetics of degradation of allura red, ponceau $4 \mathrm{R}$ and carmosine dyes with potassium ferrioxalate complex in the presence of $\mathrm{H}_{2} \mathrm{O}_{2}$. Chemosphere, 2009, 76(8), 1088-1093 DOI: 10.1016/j.chemosphere.2009.04.033

[26] Skounas, S.; Methenitis, C.; Pneumatikakis, G.; Morcellet, M.: Kinetic studies and mechanism of hydrogen peroxide catalytic decomposition by $\mathrm{Cu}$ (II) complexes with polyelectrolytes derived from 1alanine and glycylglycine. Bioinorg. Chem. Appl., 2010, 2010, 1-9 DOI: 10.1155/2010/643120

[27] Sun, Z.; Xiao, C.; Hussain, F.; Zhang, G.: Synthesis of stable and easily recycled ferric oxides assisted by Rhodamine B for efficient degradation of organic pollutants in heterogeneous photo-Fenton system. J. Clean. Prod., 2018, 196, 1501-1507 DOI: 10.1016/j.jclepro.2018.06.122

[28] Isari, A. A.; Payan, A.; Fattahi, M.; Jorfi, S.; Kakavandi, B.: Photocatalytic degradation of rhodamine $\mathrm{B}$ and real textile wastewater using $\mathrm{Fe}$ doped $\mathrm{TiO}_{2}$ anchored on reduced graphene oxide $\left(\mathrm{Fe}-\mathrm{TiO}_{2} / \mathrm{rGO}\right)$ : characterization and feasibility, mechanism and pathway studies. Appl. Surf. Sci., 2018, 462, 549-564 DOI: 10.1016/j.apsusc.2018.08.133

[29] Samavati, A.; Ismail, A.: Antibacterial properties of copper-substituted cobalt ferrite nanoparticles synthesized by co-precipitation method. Particuology, 2017, 30, 158-163 DOI: 10.1016/j.partic.2016.06.003

[30] Hoshino, N.; Kimura, T.; Hayakawa, F.; Yamaji, A.; Ando, T.: Bactericidal activity of catechincopper (II) complexes against Staphylococcus aureus compared with Escherichia coli. Lett. Appl. Microbiol., 2000, 31(3), 213-217 DOI: 10.1046/j.13652672.2000.00800.x

[31] Hu, C. H.; Xia, M. S.: Adsorption and antibacterial effect of copper-exchanged montmorillonite on Escherichia coli $\mathrm{K}_{88}$. Appl. Clay Sci., 2006, 31(3-4), 180-184 DOI: 10.1016/j.clay.2005.10.010 